University of Nebraska - Lincoln

DigitalCommons@University of Nebraska - Lincoln

Agronomy \& Horticulture -- Faculty Publications

Agronomy and Horticulture Department

2006

\title{
Effect of nitrogen addition on the comparative productivity of corn and velvetleaf (Abutilon theophrasti)
}

\author{
Darren C. Barker \\ Pioneer Hi-Bred International \\ Stevan Z. Knezevic \\ University of Nebraska-Lincoln, sknezevic2@unl.edu \\ Alex R. Martin \\ University of Nebraska-Lincoln \\ Daniel T. Walters \\ University of Nebraska-Lincoln \\ John L. Lindquist \\ University of Nebraska-Lincoln, jlindquist1@unl.edu
}

Follow this and additional works at: https://digitalcommons.unl.edu/agronomyfacpub

Part of the Plant Sciences Commons

Barker, Darren C.; Knezevic, Stevan Z.; Martin, Alex R.; Walters, Daniel T.; and Lindquist, John L., "Effect of nitrogen addition on the comparative productivity of corn and velvetleaf (Abutilon theophrasti)" (2006). Agronomy \& Horticulture -- Faculty Publications. 418.

https://digitalcommons.unl.edu/agronomyfacpub/418

This Article is brought to you for free and open access by the Agronomy and Horticulture Department at DigitalCommons@University of Nebraska - Lincoln. It has been accepted for inclusion in Agronomy \& Horticulture -Faculty Publications by an authorized administrator of DigitalCommons@University of Nebraska - Lincoln. 


\section{Effect of nitrogen addition on the comparative productivity of corn and velvetleaf (Abutilon theophrasti)}

\author{
Darren C. Barker \\ Pioneer Hi-Bred International, Inc., York, \\ NE 68467
}

Stevan Z. Knezevic

Haskell Agricultural Laboratory, University of Nebraska, Concord, NE 68728

\author{
Alex R. Martin \\ Daniel T. Walters \\ Department of Agronomy and Horticulture, \\ University of Nebraska, Lincoln, NE 68583-0915 \\ John L. Lindquist \\ Corresponding Author. Department of Agronomy \\ and Horticulture, University of Nebraska, Lincoln, \\ NE 68583-0915; jlindquist1@unl.edu
}

\begin{abstract}
Weeds that respond more to nitrogen fertilizer than crops may be more competitive under high nitrogen $(\mathrm{N})$ conditions. Therefore, understanding the effects of nitrogen on crop and weed growth and competition is critical. Field experiments were conducted at two locations in 1999 and 2000 to determine the influence of varying levels of $\mathrm{N}$ addition on corn and velvetleaf height, leaf area, biomass accumulation, and yield. Nitrogen addition increased corn and velvetleaf height by a maximum of 15 and $68 \%$, respectively. $\mathrm{N}$ addition increased corn and velvetleaf maximum leaf area index (LAI) by up to 51 and $90 \%$. Corn and velvetleaf maximum biomass increased by up to 68 and $89 \%$ with $\mathrm{N}$ addition. Competition from corn had the greatest effect on velvetleaf growth, reducing its biomass by up to $90 \%$ compared with monoculture velvetleaf. Corn response to $\mathrm{N}$ addition was less than that of velvetleaf, indicating that velvetleaf may be most competitive at high levels of nitrogen and least competitive when nitrogen levels are low. Corn yield declined with increasing velvetleaf interference at all levels of $\mathrm{N}$ addition. However, corn yield loss due to velvetleaf interference was similar across $\mathrm{N}$ treatments except in one siteyear, where yield loss increased with increasing $\mathrm{N}$ addition. Corn yield loss due to velvetleaf interference may increase with increasing $N$ supply when velvetleaf emergence and early season growth are similar to that of corn.
\end{abstract}

Nomenclature: Velvetleaf, Abutilon theophrasti Medic. ABUTH; corn, Zea mays L. 'Pioneer 33A14'.

Key words: Functional growth analysis, functional equilibrium, leaf area index, optimal partitioning, nitrogen use efficiency.
The canopy architecture of velvetleaf makes it a strong competitor for light (Lindquist and Mortensen 1999). However, velvetleaf growth, reproductive output, and competitiveness are all sensitive to nutrient supply (Parrish and Bazzaz 1982a, 1982b), timing of nutrient addition (Benner and Bazzaz 1985, 1987; Harbur and Owen 2004), and maternal nutrient regime (Wulff and Bazzaz 1992) but not the spatial heterogeneity of nutrient availability within the rhizosphere (Casper and Cahill 1996). Velvetleaf growth was most sensitive to nutrient supply at planting (Benner and Bazzaz 1987). Understanding the influence of nutrients, especially nitrogen $(\mathrm{N})$, on crop-weed competition is important because it may be possible to use nitrogen management in an integrated weed management program.

Most $\mathrm{C}_{4}$ species use $\mathrm{N}$ more efficiently than $\mathrm{C}_{3}$ species (Nieto and Staniforth 1961; Okafor and DeDatta 1976; Tollenaar et al. 1994). Because corn is a $\mathrm{C}_{4}$ and velvetleaf, a $\mathrm{C}_{3}$ species, it is expected that corn will be the more efficient user of $\mathrm{N}$, especially when $\mathrm{N}$ supply is limiting (Harbur and Owen 2004; Lindquist 2001). High levels of nutrient application do not always favor the crop over the weed (Qasem 1992). Carlson and Hill (1985) showed that wheat yield loss resulting from wild oat competition increased with increasing nitrogen application. High nutrient supply often favors weed vegetative growth and may provide little added benefit in crop yield (DiTomaso 1995). The increased crop loss from weed competition at high fertility may be due to the greater plasticity of weeds in responding to available resources.

Plants typically partition a greater proportion of new growth to roots under conditions of limited nitrogen sup- ply (Agren and Ingestad 1987; Bonifas et al. 2005; PerezLeroux and Long 1994). This provides the plants with greater root mass and volume so that more nitrogen can be acquired and $\mathrm{N}$ concentration in new leaves can be optimized. However, the greater investment in roots comes at the expense of leaf growth (Bonifas and Lindquist 2006), which subsequently limits potential growth rate. Because corn is a more efficient user of nitrogen, velvetleaf must partition a relatively greater proportion of new growth to roots under low $\mathrm{N}$, resulting in a greater reduction in leaf area growth compared with corn (Bonifas et al. 2005). However, when nitrogen is nonlimiting, velvetleaf will partition most of its growth into leaves and stems. The plant is taller and has a greater leaf area, making it more competitive with corn for light than when nitrogen is limiting. Therefore, we hypothesize that velvetleaf height, leaf area, and biomass accumulation will have a greater response to nitrogen addition than corn. As a result of the different growth response of the two species, we also hypothesize that corn yield loss due to velvetleaf competition will increase with increasing nitrogen supply. The objectives of this research were to determine the influence of variable nitrogen addition on corn and velvetleaf height, leaf area, and aboveground biomass accumulation, and corn yield and yield loss in mixtures.

\section{Materials and Methods}

\section{Field Experiments}

Field experiments were conducted at the Agricultural Research and Development Center near Mead, NE 
TABLE 1. Monthly rainfall and irrigation amounts and minimum, maximum, and mean average daily temperatures for the months of May, June, July, August, and September in 1999 and 2000. Thirty-year average precipitation and temperatures for these months are included for reference.

\begin{tabular}{|c|c|c|c|c|c|c|c|c|c|}
\hline \multirow[b]{2}{*}{ Site $^{\mathrm{a}}$} & \multirow[b]{2}{*}{ Year } & \multirow[b]{2}{*}{ Month } & \multicolumn{2}{|c|}{ Water supply } & \multicolumn{3}{|c|}{ Temperature } & \multicolumn{2}{|c|}{$30-y r$ average } \\
\hline & & & Rainfall & Irrigation & Min & Max & Mean & Rainfall & Temp \\
\hline & & & 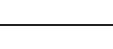 & & & $-\mathrm{C}-$ & 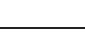 & $\mathrm{mm}$ & $\mathrm{C}$ \\
\hline & & June & 128 & 0 & 15 & 26 & 21 & 107 & 22 \\
\hline & & July & 56 & 0 & 20 & 32 & 26 & 83 & 25 \\
\hline & & Aug & 80 & 0 & 16 & 28 & 22 & 86 & 23 \\
\hline & & June & 152 & 51 & 15 & 29 & 22 & 107 & 22 \\
\hline & & July & 88 & 51 & 18 & 29 & 24 & 83 & 25 \\
\hline & & Aug & 30 & 51 & 19 & 31 & 25 & 86 & 23 \\
\hline & & Sept & 16 & 0 & 11 & 28 & 20 & 88 & 18 \\
\hline \multirow[t]{6}{*}{ NEREC } & 1999 & May & 87 & 0 & 10 & 22 & 16 & 98 & 16 \\
\hline & & June & 181 & 0 & 15 & 25 & 20 & 106 & 22 \\
\hline & & June & 157 & 0 & 13 & 26 & 20 & 106 & 22 \\
\hline & & July & 45 & 51 & 18 & 28 & 23 & 79 & 24 \\
\hline & & Aug & 31 & 76 & 17 & 29 & 23 & 74 & 23 \\
\hline & & Sept & 8 & 25 & 10 & 26 & 18 & 67 & 17 \\
\hline
\end{tabular}

a Abbreviations: ARDC, Agricultural Research and Development Center near Mead, NE; NEREC, Northeast Research and Extension Center near Concord, NE.

(ARDC) and at the Northeast Research and Extension Center near Concord, NE (NEREC) in 1999 and 2000.

\section{Agricultural Research and Development Center}

Soil type at the site was a Sharpsburg silty clay loam (fine, smectitic, mesic, Typic Argiudoll) with a $\mathrm{pH}$ of 6.7 to 6.8 and $3.3 \%$ soil organic carbon (SOC). Phosphorus (P) was broadcast-applied as $0-46-0$ at a rate of $48 \mathrm{~kg} \mathrm{P}$ $\mathrm{ha}^{-1}$ in 1999 , based on soil test. No phosphorus was required in 2000.

The experiment was designed as a randomized complete block with 16 plots and four replications. Treatments included four rates of nitrogen application and four corn-velvetleaf plots (one corn and one velvetleaf monoculture and two corn-velvetleaf mixture plots). The highest nitrogen application rate was determined based on a $12.5 \mathrm{Mg} \mathrm{ha}^{-1}$ corn yield goal and residual soil nitrogen as determined by soil tests. Nitrogen was applied at rates of $0,45,90$, and $180 \mathrm{~kg} \mathrm{~N} \mathrm{ha}^{-1}$ and $0,60,120$, and $240 \mathrm{~kg} \mathrm{~N} \mathrm{ha}^{-1}$ in 1999 and 2000, respectively. Mixture treatments included corn and velvetleaf in mixture with 65,800 corn plants $\mathrm{ha}^{-1}$ and velvetleaf at 26,300 plants ha $^{-1}$ ( 2 plants $\mathrm{m}^{-1}$ of corn row) or 131,600 plants ha ${ }^{-1}$ (10 plants $\mathrm{m}^{-1}$ of corn row). Each experimental unit (EU) was 6 by $9 \mathrm{~m}$ in 1999, although velvetleaf monoculture plots were split to obtain two velvetleaf monoculture density treatments (i.e., EU was 3 by $9 \mathrm{~m}$ ). Each $\mathrm{EU}$ was increased to 6 by $10.5 \mathrm{~m}$ in 2000 .

The field was previously cropped with corn and disked twice in spring followed by field cultivation in 1999. The 2000 field was moldboard-plowed in the fall of 1999, then disked and field cultivated in spring for seedbed preparation. Corn ('Pioneer 33A14') was seeded in rows spaced $0.76 \mathrm{~m}$ apart on May 3 in both 1999 and 2000. Tefluthrin was applied at a rate of $0.15 \mathrm{~kg}$ ai ha- at planting for early season insect control. Untreated velvetleaf seeds (100 times the desired density) were seeded directly into the corn rows at a depth of $1 \mathrm{~cm}$ using a handpush planter immediately after corn seeding. Corn and velvetleaf reached $50 \%$ emergence on May 16 and 18 , 1999, and on May 9 and 11, 2000, respectively. Nitrogen was applied as ammonium nitrate granules using a calibrated wheel-driven fertilizer spreader on May 3, 1999, and May 2, 2000.

Velvetleaf treatment densities were established by handthinning to the appropriate weed density beginning May 25, 1999, and May 23, 2000. Weeds other than velvetleaf were removed by hand as needed and by interrow cultivation on June 15, 1999. No cultivation was done in 2000. Corn began anthesis on July 21, 1999 (774 growing degree days [gdd]), and July 11, 2000 (713 gdd), and physiological maturity was reached on September 9 (1,445 gdd), and August 30 (1,416 gdd), in 1999 and 2000 , respectively. Irrigation was not available in 1999 , and was provided throughout the growing season in 2000, with approximately $51 \mathrm{~mm}$ of water applied once every 2 to 3 wk (Table 1).

\section{Northeast Research and Extension Center}

Soil in 1999 was a Kennebec silt loam, 0 to 2\% slope (Fine-silty, mixed, superactive, mesic Cumulic Hapludoll) with a pH of 6.5 and $2.8 \%$ SOC. The soil in 2000 was a Moody silt loam, 0 to $2 \%$ slope (Fine-silty, mixed, mesic Udic Haplustolls) with a pH of 6.6 and $3.0 \%$ SOC. 
TABLE 2. Corn maximum height $\left(\mathrm{HT}_{\max }\right)$ and thermal time of maximum absolute growth rate ( $a / b$ from Equation 1 fitted to HT on growing degree days [gdd]) as influenced by nitrogen supply and mixture treatments in 1999 and 2000. Within columns and years, means followed by different letters are different at $\mathrm{P}<0.05$., $\mathrm{b}$

\begin{tabular}{|c|c|c|c|c|c|c|c|c|}
\hline Year & $\begin{array}{c}\text { Velvetleaf } \\
\text { density }\end{array}$ & $\mathrm{N}_{\mathrm{trt}}$ & $\mathrm{HT}_{\max }$ & $a$ & $b$ & $a / b$ & rmse & $\sim r^{2}$ \\
\hline & & $\mathrm{kg} \mathrm{N} \mathrm{ha}^{-1}$ & $\mathrm{~cm}$ & & & gdd & & \\
\hline \multirow[t]{4}{*}{1999} & & 0 & $224 \mathrm{~b}$ & 2.96 & 0.0057 & $519 \mathrm{a}$ & 233.5 & 0.96 \\
\hline & & 45 & $238 \mathrm{ab}$ & 2.94 & 0.0063 & $467 \mathrm{~b}$ & 218.2 & 0.97 \\
\hline & & 90 & $250 \mathrm{a}$ & 2.88 & 0.0062 & $465 \mathrm{~b}$ & 246.7 & 0.97 \\
\hline & & 180 & $257 \mathrm{a}$ & 3.05 & 0.0066 & $462 \mathrm{~b}$ & 200.7 & 0.98 \\
\hline \multirow[t]{7}{*}{2000} & & 0 & $282 \mathrm{c}$ & 3.85 & 0.0075 & $513 \mathrm{a}$ & 140.2 & 0.99 \\
\hline & & 60 & $287 \mathrm{~b}$ & 3.88 & 0.0076 & $511 \mathrm{a}$ & 89.6 & 0.99 \\
\hline & & 120 & $291 \mathrm{a}$ & 3.98 & 0.0077 & $517 \mathrm{a}$ & 74.9 & 0.99 \\
\hline & & 240 & $290 \mathrm{ab}$ & 4.02 & 0.0078 & $515 \mathrm{a}$ & 127.1 & 0.99 \\
\hline & 0 & & $284 \mathrm{~b}$ & 3.93 & 0.0077 & $510 \mathrm{~b}$ & 97.5 & 0.99 \\
\hline & 2 & & $290 \mathrm{a}$ & 4.00 & 0.0077 & $519 a$ & 104.0 & 0.99 \\
\hline & 10 & & $287 \mathrm{ab}$ & 3.89 & 0.0075 & 519 a & 130.8 & 0.99 \\
\hline
\end{tabular}

${ }^{a}$ Corn height was affected by nitrogen $(\mathrm{N})$ application treatment in both years and by velvetleaf density treatment in 2000 . There was no interaction between $\mathrm{N}$ application and velvetleaf density in either year.

b Abbreviations: $\mathrm{N}_{\text {trt }}, \mathrm{N}$ treatment; rmse, residual mean square error.

The experiment was designed as a split plot with 12 treatments and four replications. Main plot treatments included four rates of $\mathrm{N}$ application, and subplots included three corn-velvetleaf densities. The highest nitrogen application rate was determined at the ARDC as described above. Nitrogen was applied at rates of $0,45,90$, and $180 \mathrm{~kg} \mathrm{~N} \mathrm{ha}{ }^{-1}$ and $0,60,120$, and $240 \mathrm{~kg} \mathrm{~N} \mathrm{ha}^{-1}$, in 1999 and 2000, respectively. Mixture treatments included corn in monoculture and in mixture with velvetleaf at densities of 26,300 plants ha ${ }^{-1}$ ( 2 plants $\mathrm{m}^{-1}$ of corn row) and 131,600 plants ha $\mathrm{h}^{-1}$ (10 plants $\mathrm{m}^{-1}$ of corn row). Each experimental unit was 4.5 by $10.5 \mathrm{~m}$ in both 1999 and 2000 .

Fields were previously cropped with corn and disked twice followed by field cultivation for seedbed preparation. Corn (Pioneer) was seeded in rows spaced $0.76 \mathrm{~m}$ apart to achieve 65,800 plants ha ${ }^{-1}$ on May 14, 1999, and May 11, 2000. Tefluthrin insecticide was applied at $0.15 \mathrm{~kg} \mathrm{ha}^{-1}$ at planting for early season insect control. Untreated velvetleaf seeds were seeded directly into the corn row using a hand-push planter immediately after corn seeding. Corn and velvetleaf reached $50 \%$ emergence on May 24 and 26 in 1999, and on May 20 and 21 in 2000 , respectively. Nitrogen was applied as ammonium nitrate granules using a calibrated wheel-driven fertilizer spreader on May 14, 1999, and May 11, 2000.

Velvetleaf densities were established by hand-thinning to the appropriate weed density beginning on June 25, 1999, and June 16, 2000. Weeds other than velvetleaf were removed by hand as needed and by interrow cultivation on June 25,1999 , and June 16, 2000. Corn began anthesis on July 31, 1999 (786 gdd), and July 26, 2000 (768 gdd), and physiological maturity was reached on September 29 (1,357 gdd), and 14 (1,477), in 1999 and 2000 , respectively. Irrigation was not available in 1999 but was applied with a lateral-move irrigation system in 2000 (Table 1).

\section{Data Collection (ARDC site only)}

Destructive plant samples were periodically taken in each experimental unit at the ARDC site to quantify crop and weed growth and canopy dynamics. The first sample was taken on May 24, 1999 (76 gdd after crop emergence), and May 15, 2000 (48 gdd). Sampling continued weekly for the next 10 wk and, thereafter, every-other week, when samples were alternated among treatments (the high and low $\mathrm{N}$ application treatments were taken one week and the two middle $\mathrm{N}$ treatments the next). Plants within a $1-\mathrm{m}$ section of row were sampled from the second, third, sixth, or seventh row of each experimental unit of the corn or mixture treatments, or from the second, third, or fourth row of each velvetleaf monoculture treatment. At least $1 \mathrm{~m}$ of row and the adjacent row were left intact between each sample area to ensure no edge effects of sampling. Plant height was determined for each plant within the sampled area before clipping plants at the soil surface. Before the sixth-leaf stage, corn height was measured to the extended tip of the tallest leaf. After a distinct bend was observed in corn leaves, height was measured to the tallest point on the undisturbed plant. After tassel emergence, height was measured to the top of the tassel. Velvetleaf height was measured at the tallest point on the plant throughout the season. Plants were then separated into stems, leaves, dead leaves, and reproductive tissues, and green leaf area was determined using an area meter. ${ }^{1}$ Young leaves were unfurled for this measurement, and dead leaf material was removed. Tissues were then dried at $60 \mathrm{C}$ to constant weight.

\section{Grain Yield (ARDC and NEREC)}

Plots at both ARDC and NEREC were hand-harvested for grain yield at the end of each growing season. At ARDC, $15 \mathrm{~m}$ of row was harvested within rows four and five of each EU. At NEREC, $15 \mathrm{~m}$ of row were harvested from rows three and four of each EU. Measurements of grain weight and moisture were obtained after grain was shelled. Grain yield is reported in units of $\mathrm{kg}$ grain ha $\mathrm{ha}^{-1}$ corrected to $15.5 \%$ moisture.

\section{Weather Data}

Daily weather data were obtained through the High Plains Climate Center from an automated weather station 


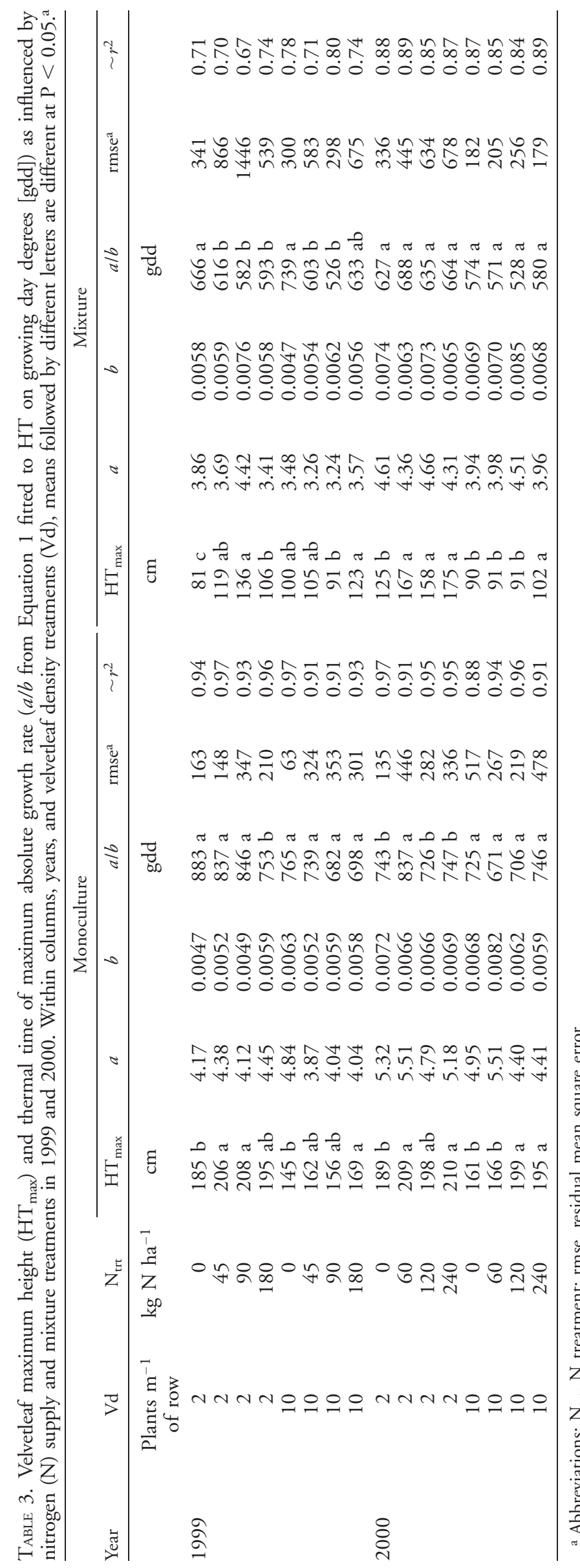

approximately $0.5 \mathrm{~km}$ from the experimental fields (Table $1)$. Thermal units (gdd) accumulated from corn emergence were calculated using gdd $=\Sigma \min \left(\left[\left\{T_{\max }+T_{\min }\right\} /\right.\right.$ 2] - $\left.T_{\mathrm{b}}, 20\right)$, where $T_{\max }$ and $T_{\min }$ are maximum and minimum daily air temperatures and $T_{\mathrm{b}}$ is the base temperature for development $(10 \mathrm{C}$ was used for both corn and velvetleaf).

\section{Models, Calculations and Assumptions}

Corn and velvetleaf growth in canopy height (HT), leaf area index (LAI), and biomass per unit area as a function of thermal time (gdd) were determined for each species within each EU. Leaf area index was determined from leaf area of harvested plants and plant density. To quantify growth over time as influenced by $\mathrm{N}$ application and mixture treatment, data were regressed on thermal units (gdd) accumulated from emergence using the Richard's function (Hunt 1982):

$$
Y=\frac{Y_{\max }}{1+\exp (a-b g d d)^{1 / c}}
$$

where $Y_{\max }$ represents maximum HT, LAI, or biomass and $a, b$, and $c$ are shape coefficients. The combination $b /(c$ +1 ) represents a weighted mean relative growth rate and $Y_{\max } \mathrm{b} /(2[c+2])$ is a weighted mean absolute growth rate over the entire growth period (Hunt 1982). Note that when $c=1$, Equation 1 simplifies to the logistic function, which is symmetric around the inflection point. The ratio $a / b$ defines the thermal time at which the inflection point occurs (when $c=1$ ), which is also the thermal time from emergence when maximum absolute growth rate occurs. Some caution is needed when interpreting this ratio because its value also is highly correlated with $Y_{\max }$ (i.e., taller plants will reach $a / b$ later). Only LAI from emergence to the beginning of senescence were used in the analysis of LAI. Corn yield loss in mixture treatments was calculated as $100(1-$ [weedy yield/mean weed-free yield]).

\section{Statistical Analysis}

To evaluate the effects of nitrogen supply and mixture treatment on height, LAI, and biomass growth, Equation 1 was fitted to these data for each experimental unit using PROC NLIN (SAS 1990). Preliminary analyses indicated that the $c$ parameter in Equation 1 did not differ from 1 in the majority of these regressions, so the simpler logistic function was used for all analyses discussed hereafter. $\mathrm{Pa}$ rameter estimates obtained for each EU were then subjected to ANOVA to determine treatment effects. Within a treatment, or where treatments did not differ, data were pooled and Equation 1 was fit to the pooled data. Approximate $r^{2}$ values were calculated as $1-$ (residual sums of squares/corrected total sums of squares). The effect of $\mathrm{N}$ application and velvetleaf density treatment on corn grain yield was tested using ANOVA. ANOVA was conducted using the PROC MIXED procedure in SAS ${ }^{2}$ (Littell et al. 1996) to compute least-squares means, standard errors, and the difference between least-squared means using an LSD-like, pair-wise $t$ test to test for treatment differences at the $\alpha=0.05$ level. 
TABLE 4. Corn maximum leaf area index $\left(\mathrm{LAI}_{\max }\right)$ and thermal time of maximum absolute growth rate of LAI $(a / b$ from Equation 1 fitted to LAI on growing degree days [gdd]) as influenced by nitrogen (N) supply and mixture treatments in 1999 and 2000 . Within columns, years and velvetleaf density treatment means followed by different letters are different at $\mathrm{P}<0.05$. . $^{\mathrm{b}}$

\begin{tabular}{|c|c|c|c|c|c|c|c|c|}
\hline Year & $\begin{array}{l}\text { Velvetleaf } \\
\text { density }\end{array}$ & $\mathrm{N}_{\text {trt }}$ & $\mathrm{LAI}_{\max }$ & a & $b$ & $a / b$ & rmse & $\sim r^{2}$ \\
\hline & & $\mathrm{kg} \mathrm{N} \mathrm{ha}^{-1}$ & $\mathrm{~m}^{2} \mathrm{~m}^{-2}$ & & & gdd & & \\
\hline \multirow[t]{7}{*}{1999} & & 0 & $2.43 \mathrm{~d}$ & 6.25 & 0.0141 & $443 \mathrm{a}$ & 0.13 & 0.89 \\
\hline & & 45 & $2.85 \mathrm{c}$ & 7.16 & 0.0177 & $405 \mathrm{~b}$ & 0.15 & 0.91 \\
\hline & & 90 & $3.23 \mathrm{~b}$ & 6.51 & 0.0158 & $412 \mathrm{~b}$ & 0.15 & 0.93 \\
\hline & & 180 & $3.68 \mathrm{a}$ & 6.41 & 0.0154 & $416 \mathrm{~b}$ & 0.15 & 0.94 \\
\hline & 0 & & $3.85 \mathrm{~b}$ & 6.78 & 0.0147 & $461 \mathrm{a}$ & 0.07 & 0.98 \\
\hline & 2 & & $3.94 \mathrm{a}$ & 6.64 & 0.0141 & $471 \mathrm{a}$ & 0.08 & 0.97 \\
\hline & 10 & & $3.83 \mathrm{~b}$ & 6.94 & 0.0146 & $475 \mathrm{a}$ & 0.09 & 0.97 \\
\hline \multirow[t]{4}{*}{2000} & & 0 & $3.64 \mathrm{c}$ & 6.33 & 0.0137 & $462 \mathrm{a}$ & 0.082 & 0.97 \\
\hline & & 60 & $3.84 \mathrm{bc}$ & 6.90 & 0.0149 & $463 \mathrm{a}$ & 0.051 & 0.98 \\
\hline & & 120 & $3.94 \mathrm{ab}$ & 6.98 & 0.0148 & $472 \mathrm{a}$ & 0.067 & 0.98 \\
\hline & & 240 & $4.07 \mathrm{a}$ & 6.93 & 0.0145 & $478 \mathrm{a}$ & 0.085 & 0.97 \\
\hline
\end{tabular}

${ }^{a}$ Corn height was affected by $\mathrm{N}$ application treatment in both years and by velvetleaf density treatment in 1999 . There was no interaction between $\mathrm{N}$ application and velvetleaf density in either year.

${ }^{b}$ Abbreviations: $\mathrm{N}_{\text {trt }}, \mathrm{N}$ treatment; rmse, residual mean square error.

\section{Results and Discussion}

\section{Rainfall and Thermal Units}

Soil temperature at planting was $16 \mathrm{C}$ in 1999 and 20 $\mathrm{C}$ in 2000 at ARDC. Soil temperature at planting was unavailable for NEREC in 1999 and 18 C in 2000. Monthly average daily air temperature was generally cooler at ARDC in 1999, except in June, which was 1 C warmer than the 30 -yr average (Table 1 ). Monthly average temperatures at NEREC were $0.8 \mathrm{C}$ and $0.2 \mathrm{C}$ cooler than the normal during the 1999 and 2000 growing seasons, respectively. May and June 1999 were wetter than the 30-yr average at both ARDC and NEREC. However, July, August, and September 1999 monthly precipitation averages were $17 \mathrm{~mm}$ and $50 \mathrm{~mm}$ below the normal at ARDC and NEREC, respectively. May 2000 was dryer than the average at both ARDC and NEREC, but timely precipitation and irrigation resulted in above-average water deposition for the remainder of the season at both locations (Table 1).

\section{Canopy Height}

Equation 1 explained at least $96 \%$ of the variance in corn height in relation to thermal time from emergence (Table 2). Corn generally reached a greater height $\left(\mathrm{HT}_{\max }\right)$ and had greater season-long, relative-height growth rate (b/2) in 2000 than in 1999. Corn height growth was affected by $\mathrm{N}$ addition but not velvetleaf density treatment in 1999. Both $\mathrm{N}$ addition and velvetleaf density treatments, but not their interaction, affected corn height growth in 2000. Addition of nitrogen generally increased corn height in both years and resulted in an earlier time of maximum height growth rate in 1999.

Corn reached a maximum height of $257 \mathrm{~cm}$ in the 180 $\mathrm{N}$ application treatment in 1999 and $290 \mathrm{~cm}$ in the equivalent treatment in 2000. Corn $\mathrm{HT}_{\max }$ was reduced by 13 and $3 \%$ in the $0 \mathrm{~N}$ compared with the highest $\mathrm{N}$ treatment in 1999 and 2000, respectively (Table 2). Thermal time of maximum corn height growth rate $(a / b)$ was an average of $10 \%$ greater (54 gdd, or approximately $3 \mathrm{~d}$ later) in the zero $\mathrm{N}$ treatment compared with other $\mathrm{N}$ treatments in 1999, whereas no differences in time of maximum height growth rate occurred across any $\mathrm{N}$ treatments in 2000. Competition from velvetleaf at 2 plants $\mathrm{m}^{-1}$ row increased corn $\mathrm{HT}_{\max }$ by $2 \%$, and $a / b$ occurred 9 gdd later compared with corn monoculture in 2000.

Equation 1 explained at least $67 \%$ of the variance in velvetleaf height in relation to thermal time from emergence (Table 3). As expected given its greater genetic diversity and phenotypic plasticity, velvetleaf height growth is more variable than that of corn, especially when grown in competition with corn. Nitrogen addition, velvetleaf density, crop presence or absence, and their interactions all affected velvetleaf height growth in both years.

Corn presence had the strongest negative effect on velvetleaf height growth, reducing estimated velvetleaf $\mathrm{HT}_{\max }$ by 40 and $35 \%$ (from 180 and $190 \mathrm{~cm}$ ) across all other treatments in 1999 and 2000, respectively. Velvetleaf reached an $\mathrm{HT}_{\max }$ that was 15 and $24 \%$ shorter in the 10 compared with the 2 plants $\mathrm{m}^{-1}$ row density treatments in 1999 and 2000, respectively. Because the velvetleaf was taller, thermal time of maximum-height growth rate was 9 (67 gdd) and 8\% (60 gdd) later in the 2 compared with the 10 plants $\mathrm{m}^{-1}$ row treatment. Velvetleaf $\mathrm{HT}_{\max }$ was 19 and $16 \%$ smaller in the 0 compared with all other $\mathrm{N}$ treatments in 1999 and 2000, respectively (main effect results not shown).

Estimated velvetleaf maximum height $\left(\mathrm{HT}_{\max }\right)$ in monoculture at 2 plants $\mathrm{m}^{-1}$ row reached 208 and 210 $\mathrm{cm}$ in 1999 and 2000, respectively, and was reduced (by 11 and $10 \%$ ) only in the $0 \mathrm{~N}$ treatment in both years (Table 3). Thermal time of maximum velvetleaf height growth rate occurred $15 \%$ earlier (130 gdd, or about $7 \mathrm{~d}$ ) in the $180 \mathrm{~N}$ compared with the $0 \mathrm{~N}$ treatment in 1999. Although the estimated maximum velvetleaf height in the $60-\mathrm{kg} \mathrm{N} \mathrm{ha}{ }^{-1}$ treatment reached $209 \mathrm{~cm}$ in 2000, time of maximum-height growth rate in that treatment occurred 100 gdd (ca. 5 d) later, indicating that overall height growth was delayed at low N. Monoculture-grown velvetleaf at 10 plants $\mathrm{m}^{-1}$ of row grew 14 and $17 \%$ taller 


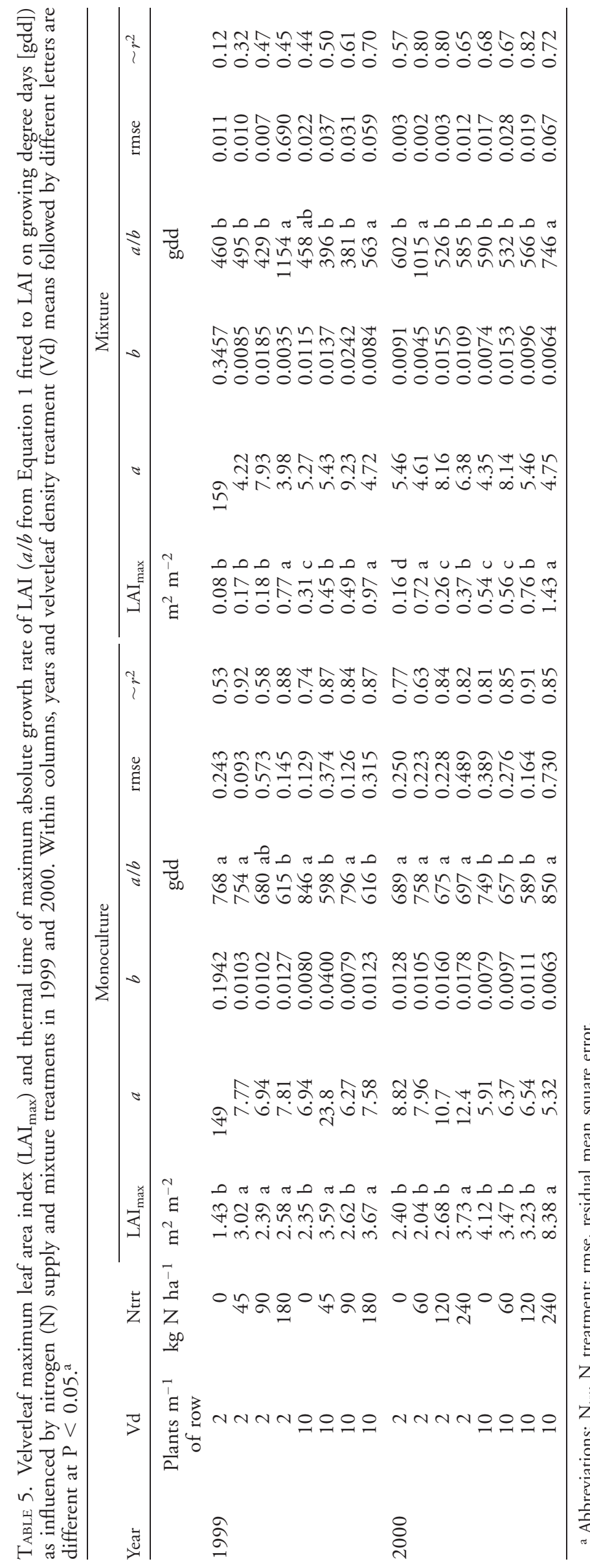

in the higher $\mathrm{N}$ treatments in 1999 and 2000, respectively.

Estimated velvetleaf maximum height $\left(\mathrm{HT}_{\max }\right)$ in mixture at 2 plants $\mathrm{m}^{-1}$ row reached 136 and $175 \mathrm{~cm}$ in 1999 and 2000, respectively, and was reduced (by 24 and 29\%) in the $0 \mathrm{~N}$ treatment (Table 3). Thermal time of maximum velvetleaf height growth rate occurred $12 \%$ later $(73$ gdd, or about $4 \mathrm{~d}$ ) in the $0 \mathrm{~N}$ compared with the $\mathrm{N}$ addition treatments in 1999. Mixture-grown velvetleaf at 10 plants $\mathrm{m}^{-1}$ of row grew 19 and $12 \%$ taller in the higher N treatments in 1999 and 2000, respectively.

Results show that competition from corn strongly reduces velvetleaf height, but velvetleaf only reduced corn height by up to $2 \%$. Velvetleaf intraspecific competition also slowed velvetleaf height development and reduced maximum height. Nitrogen addition had a positive effect on both corn and velvetleaf height growth. The effect was similar among species in monoculture, but velvetleaf in mixture with corn was more affected by $\mathrm{N}$ addition than corn or velvetleaf growing alone.

\section{Canopy Leaf Area Index}

Equation 1 explained at least $89 \%$ of the variance in corn LAI in relation to thermal time from emergence ( $\mathrm{Ta}-$ ble 4). Corn generally reached a greater LAI $\left(\mathrm{LAI}_{\max }\right)$ in 2000 than in 1999. Corn LAI was affected by $\mathrm{N}$ addition and velvetleaf density treatments, but not their interaction, in 1999, but only by $\mathrm{N}$ addition in 2000. Addition of nitrogen generally increased corn LAI and resulted in an earlier time of maximum leaf area growth rate.

Corn reached a maximum LAI of 3.68 in the $180 \mathrm{~N}$ treatment in 1999 and 4.07 in the equivalent treatment in 2000. Estimated corn $\mathrm{LAI}_{\max }$ was reduced by 34 and $11 \%$ in the 0 compared with the highest $\mathrm{N}$ treatment in 1999 and 2000, respectively (Table 4). Thermal time of maximum corn LAI growth rate $(a / b)$ was $6 \%$ greater in the $0 \mathrm{~N}$ treatment compared with other $\mathrm{N}$ treatments in 1999 , whereas no differences in $a / b$ occurred across $N$ treatments in 2000. Competition from velvetleaf at 2 plants $\mathrm{m}^{-1}$ of row increased corn $\mathrm{LAI}_{\max }$ by $2 \%$ compared with weed-free corn or corn in mixture with velvetleaf at 10 plants $\mathrm{m}^{-1}$ of row in 1999 , but no effect of weed density was observed in 2000 .

Equation 1 explained an average of 79 and $58 \%$ of the variation in LAI of velvetleaf grown in monoculture and mixture, respectively (Table 5). As with height growth, velvetleaf LAI is more variable than that of corn, especially in mixture. Nitrogen addition, velvetleaf density, crop presence or absence, and their interactions all affected velvetleaf LAI in both years.

Corn presence had the strongest negative effect on velvetleaf LAI growth, reducing estimated velvetleaf LAI $_{\max }$ by $87 \%$ (from 2.67 and $4.09 \mathrm{~m}^{2} \mathrm{~m}^{-2}$ ) across all other treatments in both 1999 and 2000. Velvetleaf reached an $\mathrm{LAI}_{\max }$ that was 30 and $96 \%$ greater in the 10 compared with the 2 plants $\mathrm{m}^{-1}$ of row density treatments in 1999 and 2000, respectively. Although velvetleaf LAI was greater in the 10 plants $\mathrm{m}^{-1}$ row treatment, thermal time of maximum LAI growth rate was $11 \%$ (79 gdd) earlier in 1999 and 8\% (53 gdd) later in 2000 (Table 5). Velvetleaf $\mathrm{LAI}_{\max }$ was 53 and $44 \%$ smaller in the 0 compared with 
TABLE 6. Corn maximum aboveground biomass $\left(B i o_{\max }\right)$ and thermal time of maximum absolute growth rate of biomass $(a / b$ from Equation 1 fitted to biomass on growing degree days [gdd]) as influenced by nitrogen (N) supply and mixture treatments in 1999 and 2000. Within columns, years and velvetleaf density treatment means followed by different letters are different at $\mathrm{P}<0.05$. $^{\mathrm{a}}$

\begin{tabular}{|c|c|c|c|c|c|c|c|c|}
\hline Year $^{\mathrm{b}}$ & $\begin{array}{c}\text { Velvetleaf } \\
\text { density }\end{array}$ & $\mathrm{N}_{\mathrm{trt}}$ & $B i o_{\max }$ & $a$ & $b$ & $a / b$ & rmse & $\sim r^{2}$ \\
\hline & & $\mathrm{kg} \mathrm{N} \mathrm{ha}^{-1}$ & $\mathrm{~g} \mathrm{~m}^{-2}$ & & & gdd & & \\
\hline \multirow[t]{7}{*}{1999} & & 0 & $883 \mathrm{c}$ & 4.57 & 0.0060 & 762 a & 14,302 & 0.87 \\
\hline & & 45 & $1,199 \mathrm{~b}$ & 4.17 & 0.0054 & $772 \mathrm{a}$ & 31,343 & 0.85 \\
\hline & & 90 & $1,248 \mathrm{~b}$ & 4.63 & 0.0065 & $712 \mathrm{~b}$ & 26,120 & 0.90 \\
\hline & & 180 & $1,487 \mathrm{a}$ & 4.49 & 0.0060 & $748 \mathrm{a}$ & 22,060 & 0.93 \\
\hline & 0 & & $1,369 \mathrm{a}$ & 4.43 & 0.0058 & $764 \mathrm{a}$ & 50,147 & 0.86 \\
\hline & 2 & & $1,115 \mathrm{~b}$ & 4.61 & 0.0064 & $720 \mathrm{~b}$ & 46,769 & 0.83 \\
\hline & 10 & & $1,139 \mathrm{~b}$ & 4.29 & 0.0056 & 766 a & 41,666 & 0.84 \\
\hline \multirow[t]{4}{*}{2000} & & 0 & $1,843 \mathrm{c}$ & 4.94 & .0058 & 858 a & 12,116 & 0.97 \\
\hline & & 60 & $1,991 \mathrm{~b}$ & 4.76 & .0054 & $881 \mathrm{a}$ & 8,303 & 0.98 \\
\hline & & 120 & $2,023 \mathrm{~b}$ & 4.94 & .0056 & $876 \mathrm{a}$ & 15,355 & 0.96 \\
\hline & & 240 & $2,169 \mathrm{a}$ & 4.76 & .0053 & 898 a & 9,046 & 0.98 \\
\hline
\end{tabular}

a Abbreviations: $\mathrm{N}_{\text {trt }}, \mathrm{N}$ treatment; rmse, residual mean square error.

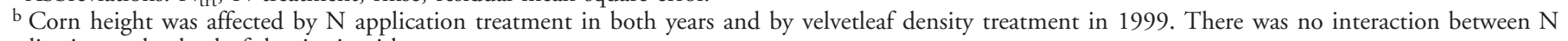
application and velvetleaf density in either year.

high $\mathrm{N}$ treatments in 1999 and 2000, respectively (main effect results not shown).

Estimated maximum velvetleaf LAI ( $\left.\mathrm{LAI}_{\max }\right)$ in monocultures at 2 plants $\mathrm{m}^{-1}$ of row reached 3.02 and 3.73 in 1999 and 2000, respectively, and was reduced by 46 and $36 \%$ in the $0 \mathrm{~N}$ compared with high $\mathrm{N}$ treatments (Table 5). This reduction was 90 and $57 \%$ in the presence of corn. Velvetleaf LAI $_{\max }$ in monoculture was reduced only in the $0 \mathrm{~N}$ treatment in 1999 but was greater only in the $240 \mathrm{~N}$ treatment in 2000. $\mathrm{N}$ addition had a greater relative affect on velvetleaf $\mathrm{LAI}_{\max }$ in mixture. Thermal time of maximum velvetleaf LAI growth rate occurred 20 and $27 \%$ earlier in the highest $\mathrm{N}$ compared with the $0 \mathrm{~N}$ treatments in 1999 and 2000, respectively. Monoculturegrown velvetleaf at 10 plants $\mathrm{m}^{-1}$ of row grew 36 and $55 \%$ less LAI in the $0 \mathrm{~N}$ compared with high $\mathrm{N}$ treatments in 1999 and 2000, whereas this difference was 68 and $62 \%$ in mixture.

The greater reduction in velvetleaf $\mathrm{LAI}_{\max }$ grown in mixture indicates that competition from corn has more influence on velvetleaf leaf area growth than intraspecific competition with velvetleaf. The greater reduction in velvetleaf $\mathrm{LAI}_{\max }$ at low $\mathrm{N}$ compared with corn indicates that $\mathrm{N}$ influences velvetleaf leaf area to a greater degree than it does to corn. Radin (1983) found that leaf area growth of dicotyledonous plants was inhibited to a greater degree than $\mathrm{C}_{4}$ cereal grains when nitrogen supply was limited. This increases the advantage in light competition for corn compared with velvetleaf at lower levels of $\mathrm{N}$. The greater influence of $\mathrm{N}$ on velvetleaf LAI compared with corn may be associated with its pattern of leaf senescence or differences among species in $\mathrm{N}$ use efficiency (Hikosaka 2005). Velvetleaf plants in the greater $\mathrm{N}$ application treatments may be able to support more leaves for longer periods of time before senescence occurs.

\section{Biomass}

Equation 1 explained at least $83 \%$ of the variance in corn aboveground biomass in relation to thermal time from emergence (Table 6). Corn generally achieved great- er biomass in 2000 than 1999. Corn biomass was affected by $\mathrm{N}$ addition and velvetleaf density treatment in 1999 but only $\mathrm{N}$ addition in 2000. Competition from velvetleaf reduced maximum corn biomass $\left(B i o_{\max }\right)$ in 1999. Nitrogen addition generally increased corn biomass in both years.

Corn reached a maximum biomass of $1,487 \mathrm{~g} \mathrm{~m}^{-2}$ in the $180 \mathrm{~N}$ treatment in 1999 and $2,169 \mathrm{~g} \mathrm{~m}^{-2}$ in the equivalent treatment in 2000. Corn $\mathrm{Bio}_{\max }$ was reduced by 41 and $15 \%$ in the $0 \mathrm{~N}$ compared with the highest $\mathrm{N}$ treatment in 1999 and 2000, respectively (Table 6). Competition from velvetleaf reduced corn $B i o_{\max }$ by $17 \%$, regardless of density, in 1999.

Equation 1 explained an average of 76 and $50 \%$ of the variation in biomass of velvetleaf grown in monoculture and mixture, respectively (Table 6). As with height and LAI growth, velvetleaf aboveground biomass is more variable than that of corn, especially in mixture. Nitrogen addition, velvetleaf density, crop presence or absence, and their interactions all affected velvetleaf biomass accumulation in both years.

Corn presence had the strongest negative effect on velvetleaf aboveground biomass, reducing estimated velvetleaf $B i o_{\max }$ by 90 and $87 \%$ (from 738 and $816 \mathrm{~g} \mathrm{~m}^{-2}$ ) across all other treatments in 1999 and 2000, respectively. Velvetleaf reached a $\mathrm{Bio}_{\max }$ that was 50 and $98 \%$ greater in the 10 compared with the 2 plants $\mathrm{m}^{-1}$ of row density treatments in 1999 and 2000, respectively. Although velvetleaf biomass was greater in the 10 plants $\mathrm{m}^{-1}$ of row treatment, thermal time of maximum biomass growth rate was $12 \%$ (128 gdd) earlier in 1999 and 7\% (66 gdd) later in 2000 (Table 7). Velvetleaf $B i o_{\max }$ was 57 and $34 \%$ smaller in the 0 compared with the highest $\mathrm{N}$ treatments in 1999 and 2000, respectively (main effect results not shown).

Estimated maximum velvetleaf biomass $\left(B i o_{\max }\right)$ in monoculture at 2 plants $\mathrm{m}^{-1}$ of row reached 2,053 and 1,539 in 1999 and 2000, respectively. The extremely large number in 1999 was offset by a long delayed time of maximum growth rate $(a / b)$ so that predicted biomass at 


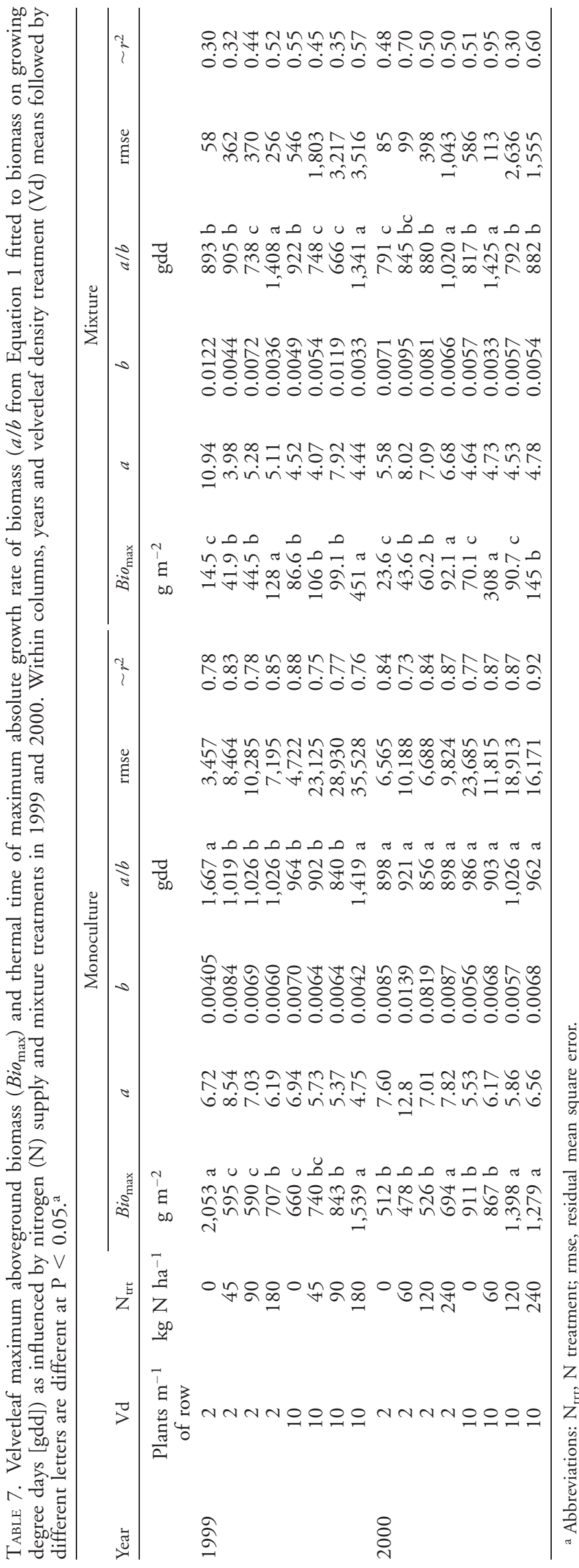

the time of corn maturity (1,445 gdd from emergence) was $568 \mathrm{~g} \mathrm{~m}^{-2}$, which is lower than any other estimated $B i o_{\max }$. Using $568 \mathrm{~g} \mathrm{~m}^{-2}$ as the estimated final biomass for the $0 \mathrm{~N}$ treatment, $\mathrm{Bio}_{\max }$ was reduced by 20 and $26 \%$ in the $0 \mathrm{~N}$ compared with high $\mathrm{N}$ treatments (Table 7). This reduction was 88 and $74 \%$ in the presence of corn. Monoculture grown velvetleaf at 10 plants $\mathrm{m}^{-1}$ of row grew 57 and $29 \%$ less biomass in the $0 \mathrm{~N}$ compared with high $\mathrm{N}$ treatments in 1999 and 2000, whereas this difference was 81 and $52 \%$ in mixture.

Warmer growing conditions at planting in 2000 allowed for an earlier and more even plant emergence, which usually leads to increases in corn biomass production (Graven and Carter 1991). Experiments were irrigated in 2000, but not in 1999, and irrigation is known to cause an increase in total corn biomass production compared with nonirrigated conditions (Wienhold et. al. 1995). The difference in final corn biomass was smaller between $\mathrm{N}$ treatments in 2000 . Nitrogen was likely more available in 2000 because of increases in soil mineralization due to the greater soil moisture and because nitrogen is a mobile nutrient and its availability is influenced by soil water content (Barber and Cushman 1981).

Total aboveground biomass of monoculture-grown velvetleaf increased with increasing nitrogen application. Measured corn biomass in the zero $\mathrm{N}$ treatment at maturity was 56 to $96 \%$ of that in the highest $\mathrm{N} \mathrm{levels,}$ whereas measured velvetleaf biomass in the zero $\mathrm{N}$ treatment was only 41 to $53 \%$ that in the highest $\mathrm{N}$ treatment (data not shown). The decrease in total velvetleaf plant biomass in 0 compared with high $\mathrm{N}$ levels was greater in mixture than in monoculture in both years. Therefore, nitrogen has a greater influence on velvetleaf biomass production than it has on corn, especially in mixture.

\section{Corn Yield and Yield Loss}

Corn yield was lower at NEREC than ARDC in both years (Table 8), so locations were not combined for analysis. Differences between locations are most likely due to environmental and management differences. Based on average weather data, growing season length is expected to be 100 gdd shorter at NEREC than ARDC. Actual growing season was shorter at NEREC in 1999 but not in 2000. The lower corn population density at NEREC may have contributed to the lower yields at that site. Corn yield at both locations was lower in 1999 than 2000. Both locations experienced dryer conditions during July and August 1999. Water stress during anthesis and grain fill is known to cause early senescence (Claassen and Shaw 1970a; Jurgens et al. 1978) and reduced yields (Claussen and Shaw 1970b; Denmead and Shaw 1960; Downey 1971).

Over the past 40 to $50 \mathrm{yr}$, increases in corn yield have been closely associated with increases in the amounts of applied nitrogen (Sinclair and Muchow 1995). Monoculture corn yield increased with increasing $\mathrm{N}$ supply in all site-years (Table 8). However, the effect of competition from velvetleaf at low $\left(2\right.$ plants $\left.\mathrm{m}^{-1}\right)$ and high densities (10 plants $\mathrm{m}^{-1}$ ) varied with nitrogen application treatment. With the exception of the 45 and $60 \mathrm{~N}$ treatments in 1999 and 2000 at ARDC, yield generally decreased as weed density increased (Table 8). Mean yields were ac- 
TABLE 8. Mean corn grain yield and yield loss as influenced by nitrogen $(\mathrm{N})$ and velvetleaf density treatments at Agricultural Research and Development Center (ARDC) near Mead, NE, and the Northeast Research and Extension Center (NEREC) near Concord, NE, in 1999 and 2000. Within locations and years, means followed by different letters are different at $\mathrm{P}<0.05$ (letters in parentheses signify differences among velvetleaf density treatments). An asterisk indicates that yield loss differs among density treatments within an $\mathrm{N}$ treatment at $\mathrm{P}<0.05$.

\begin{tabular}{|c|c|c|c|c|c|c|c|}
\hline \multirow[b]{2}{*}{ Location } & \multirow[b]{2}{*}{ Year } & \multirow{2}{*}{$\begin{array}{c}\mathrm{N} \\
\text { treatment }\end{array}$} & \multicolumn{3}{|c|}{ Corn yield $\left(\mathrm{kg} \mathrm{ha}^{-1}\right)$} & \multicolumn{2}{|c|}{ Yield loss ${ }^{\mathrm{a}}(\%)$} \\
\hline & & & \multicolumn{3}{|c|}{ Velvetleaf density (plants $\mathrm{m}^{-1}$ of row) } & \multicolumn{2}{|c|}{ Velvetleaf density (plants $\mathrm{m}^{-1}$ row } \\
\hline & & $\mathrm{kg} \mathrm{ha}^{-1}$ & 0 & 2 & 10 & 2 & 10 \\
\hline \multirow[t]{8}{*}{ ARDC } & 1999 & 0 & $7,807 \mathrm{c}(\mathrm{a})$ & $7,822 \mathrm{~b}(\mathrm{a})$ & $6,592 \mathrm{c}(\mathrm{a})$ & $-1.9 \mathrm{~b}$ & $15.6 \mathrm{~b}^{*}$ \\
\hline & & 45 & $8,429 \mathrm{~b}(\mathrm{a})$ & $10,016 \mathrm{a}(\mathrm{a})$ & $8,618 \mathrm{~b}(\mathrm{a})$ & $-18.8 \mathrm{c}$ & $-2.2 c^{*}$ \\
\hline & & 90 & $12,035 \mathrm{a}(\mathrm{a})$ & $10,563 \mathrm{a}(\mathrm{a})$ & $8,561 \mathrm{~b}(\mathrm{~b})$ & $12.2 \mathrm{a}$ & $28.9 \mathrm{a}^{*}$ \\
\hline & & 180 & $11,786 \mathrm{a}(\mathrm{a})$ & $11,308 \mathrm{a}(\mathrm{a})$ & $10,987 \mathrm{a}(\mathrm{a})$ & $4.1 \mathrm{~b}$ & $6.8 \mathrm{~b}^{*}$ \\
\hline & 2000 & 0 & $13,336 \mathrm{~b}(\mathrm{a})$ & $12,586 \mathrm{a}(\mathrm{ab})$ & $11,507 \mathrm{a}(\mathrm{b})$ & $5.6 \mathrm{a}$ & $13.7 \mathrm{a}$ \\
\hline & & 60 & $12,934 \mathrm{~b}(\mathrm{a})$ & $13,116 \mathrm{a}(\mathrm{a})$ & 13,899 a(a) & $-1.4 \mathrm{~b}$ & $-7.5 \mathrm{~b}$ \\
\hline & & 120 & $14,450 \mathrm{a}(\mathrm{a})$ & $13,573 \mathrm{a}(\mathrm{a})$ & $13,312 \mathrm{a}(\mathrm{a})$ & $6.1 \mathrm{a}$ & $7.9 \mathrm{a}$ \\
\hline & & 240 & $14,080 \mathrm{a}(\mathrm{a})$ & $12,975 \mathrm{a}(\mathrm{ab})$ & $12,254 \mathrm{a}(\mathrm{b})$ & $7.9 \mathrm{a}$ & $13.0 \mathrm{a}$ \\
\hline \multirow[t]{8}{*}{ NEREC } & 1999 & 0 & 6,566 b(a) & 6,184 a(a) & 6,175 a(a) & $5.8 \mathrm{~b}$ & $6.0 \mathrm{~b}$ \\
\hline & & 45 & $7,180 \mathrm{ab}(\mathrm{a})$ & $6,895 \mathrm{a}(\mathrm{a})$ & $5,160 \mathrm{~b}(\mathrm{~b})$ & $4.0 \mathrm{~b}$ & $28.1 \mathrm{a}^{*}$ \\
\hline & & 90 & $7,685 \mathrm{a}(\mathrm{a})$ & $6,797 \mathrm{a}(\mathrm{ab})$ & $6,004 \mathrm{ab}(\mathrm{b})$ & $11.6 \mathrm{a}$ & $21.9 \mathrm{a}^{*}$ \\
\hline & & 180 & $7,254 \mathrm{ab}(\mathrm{a})$ & $7,013 \mathrm{a}(\mathrm{ab})$ & $6,232 \mathrm{a}(\mathrm{b})$ & $3.3 \mathrm{~b}$ & $14.1 \mathrm{~b}^{*}$ \\
\hline & 2000 & 0 & $9,061 \mathrm{~b}(\mathrm{a})$ & $6,962 \mathrm{a}(\mathrm{b})$ & $6,548 \mathrm{a}(\mathrm{b})$ & $23.2 \mathrm{~b}$ & $27.7 b^{*}$ \\
\hline & & 60 & $9,687 \mathrm{ab}(\mathrm{a})$ & $8,087 \mathrm{a}(\mathrm{b})$ & $6,198 \mathrm{a}(\mathrm{c})$ & $16.5 \mathrm{~b}$ & $36.0 \mathrm{~b}^{*}$ \\
\hline & & 120 & $10,169 \mathrm{ab}(\mathrm{a})$ & $7,587 \mathrm{a}(\mathrm{b})$ & 6,449 a(b) & $25.4 \mathrm{ab}$ & $36.6 \mathrm{ab}^{*}$ \\
\hline & & 240 & $10,599 \mathrm{a}(\mathrm{a})$ & $7,126 \mathrm{a}(\mathrm{b})$ & $6,181 \mathrm{a}(\mathrm{b})$ & $32.8 \mathrm{a}$ & $41.7 \mathrm{a}^{*}$ \\
\hline
\end{tabular}

${ }^{\text {a } C o r n ~ y i e l d ~ l o s s ~ w a s ~ c a l c u l a t e d ~ a s ~} 100(1-$ [weedy yield/mean weed-free yield]).

tually larger for corn grown with velvetleaf than for corn grown in monoculture in the 45 and $60 \mathrm{~N}$ application treatments. These results imply that low levels of nitrogen addition may have a slight negative impact on corn yield in monoculture, though it is not clear why. Similar trends in yield were not observed at NEREC, indicating that environmental factors may play a role in these interactions.

Corn yield loss was greater at NEREC than ARDC in both years (Table 8). Velvetleaf emergence at NEREC in 2000 was only $11 \mathrm{gdd}(1 \mathrm{~d})$ behind that of corn, the shortest thermal time difference in corn and velvetleaf emergence. Thinning of weeds at NEREC was done after initial thinning at ARDC was completed, and initial weed populations at NEREC in both years were higher than that of ARDC. Although detailed biomass measurements were only taken at ARDC, velvetleaf was generally observed to be taller and leafier at NEREC in both years. Earlier weed emergence, delay of thinning, and lower corn population may have led to increased growth and competition from velvetleaf at earlier stages of corn development, which may have contributed to the greater yield loss at NEREC.

Nitrogen addition and velvetleaf density, but not their interaction, affected yield loss at ARDC in 1999, but only $\mathrm{N}$ treatment affected yield loss in 2000. Nitrogen and velvetleaf density treatments affected yield loss at NEREC in both years, and their interaction was significant in 2000. Corn yield loss increased with increasing velvetleaf density at ARDC in 1999. Corn yield loss was smallest in the 45 and $60 \mathrm{~N}$ treatments at ARDC in 1999 and 2000, respectively. Corn yield loss at NEREC was greatest in the $90 \mathrm{~N}$ treatment in the low velvetleaf density mixtures in 1999 . However, in the 10 velvetleaf plants $\mathrm{m}^{-1}$ of row treatment, yield loss was lowest in the zero $\mathrm{N}$ treatment, greatest in the $45 \mathrm{~N}$ treatment, and declined with further increases of $\mathrm{N}$ in 1999. Corn yield loss increased with increasing $\mathrm{N}$ application at NEREC in 2000 (Table 8).

Velvetleaf height, LAI, and biomass accumulation responded more to $\mathrm{N}$ addition than corn, supporting our initial hypothesis. However, corn yield loss due to velvetleaf competition did not consistently increase with increasing $\mathrm{N}$ addition. The stronger competitive effects of corn on velvetleaf at ARDC diluted the $\mathrm{N}$ response of velvetleaf and its subsequent effect on corn yield loss. However, corn and velvetleaf emergence dates were similar and weed pressure was greater at NEREC than at ARDC. Therefore, corn did not have as great a competitive effect on velvetleaf at NEREC compared with ARDC, and the $\mathrm{N}$ response of velvetleaf gave it more of a competitive advantage at this location. Results of this research indicate that when velvetleaf emerges with the crop, its competitive effects on corn yield may increase with increasing $\mathrm{N}$ supply and as corn population density decreases. To minimize the positive effects of $\mathrm{N}$ application on velvetleaf growth and competitiveness, the management implications from this study suggest planting corn at the greatest density appropriate for a given environment and ensuring that velvetleaf emerges at least $2 \mathrm{~d}$ after corn emergence.

\section{Sources of Materials}

${ }^{1}$ LI-3000 area meter, LiCor, 4421 Superior Street, Lincoln, NE 68504-0425.

2 SAS Institute Inc., 100 SAS Campus Drive, Cary, NC 27513-2414.

\section{Acknowledgments}

A contribution of the University of Nebraska Agricultural Research Division, Lincoln, NE. Journal Series No. 14671. This 
research was supported in part by funds provided by the Hatch Act and by the State of Nebraska.

\section{Literature Cited}

Agren, G. I. and T. Ingestad. 1987. Root:shoot ratio as a balance between nitrogen productivity and photosynthesis. Plant Cell Environ. 10:579-586.

Barber, S. A. and J. H. Cushman. 1981. Nitrogen uptake model for agronomic crops. Pages 382-409 in J. K. Iskander, ed. Modeling Wastewater Renovation-Land Treatment. New York: Wiley.

Benner, B. L. and F. A. Bazzaz. 1985. Response of the annual Abutilon theophrasti Medic (Malvaceae) to timing of nutrient availability. Am. J. Bot. 72:320-323.

Benner, B. L. and F. A. Bazzaz. 1987. Effects of timing of nutrient addition on competition within and between two annual plant species. J. Ecol. 75:229-245.

Bonifas, K. D., D. T. Walters, K. G. Cassman, and J. L. Lindquist. 2005. The effects of nitrogen supply on root:shoot ratio in corn and velvetleaf. Weed Sci. 53:670-675.

Bonifas, K. D. and J. L. Lindquist. 2006. Predicting biomass partitioning to root versus shoot in corn and velvetleaf. Weed Sci. 54:133137.

Carlson, H. L. and J. E. Hill. 1985. Wild oat (Avena fatua) competition with spring wheat: effects of nitrogen fertilization. Weed Sci. 34: $29-33$.

Casper, B. B. and J. F. Cahill, Jr. 1996. Limited effects of soil heterogeneity on populations of Abutilon theophrasti (Malvaceae). Am. J. Bot. 83:333-341.

Claassen, M. M. and R. H. Shaw. 1970a. Water deficit effects on corn, I: vegetative components. Agron. J. 62:649-652.

Claassen, M. M. and R. H. Shaw. 1970b. Water deficit effects on corn, II: yield. Agron. J. 62:649-652.

Denmead, O. T. and R. H. Shaw. 1960. The effects of soil moisture stress at different stages of growth on the development and yield of corn. Agron. J. 52:272-274.

DiTomaso, J. M. 1995. Approaches for improving crop competitiveness through the manipulation of fertilization strategies. Weed Sci. 43: 491-497.

Downey, L. A. 1971. Effects of gypsum and drought stress on maize (Zea mays L.), I: growth, light absorption, and yield. Agron. J. 63: 569-572.

Graven, L. M. and P. R. Carter. 1991. Seed quality effect on corn performance under conventional and no-tillage systems. J. Prod. Agric. 4:366-373.

Harbur, M. M. and M.D.K. Owen. 2004. Light and growth rate effects on crop and weed responses to nitrogen. Weed Sci. 52:578-583.

Hikosaka, K. 2005. Leaf canopy as a dynamic system: ecophysiology and optimality in leaf turnover. Ann. Bot. (Lond.) 95:521-533.
Hunt, R. 1982. Plant Growth Curves: The Functional Approach to Plant Growth Analysis. Baltimore, MD: University Park Press. Pp. $135-144$

Jurgens, S. K., R. R. Johnson, and J. S. Boyer. 1978. Dry matter production and translocation in corn subjected to drought during grain fill. Agron. J. 70:678-682.

Lindquist, J. L. 2001. Light-saturated $\mathrm{CO}_{2}$ assimilation rates of corn and velvetleaf in response to leaf nitrogen and development stage. Weed Sci. 49:706-710.

Lindquist, J. L. and D. A. Mortensen. 1999. Ecophysiological characteristics of four maize hybrids and Abutilon theophrasti. Weed Res. 39:271-285.

Littell, R. C., G. A. Milliken, W. W. Stroup, and R. D. Wolfinger. 1996. SAS System for Mixed Models. Cary, NC: Statistical Analysis Systems Institute.

Nieto, J. H. and D. W. Staniforth. 1961. Corn-foxtail competition under various production conditions. Agron. J. 53:1-5.

Okafor, L. I. and S. K. DeDatta. 1976. Competition between upland rice and purple nutsedge for nitrogen, moisture and light. Weed Sci. 24:43-46.

Parrish, J.A.D. and F. A. Bazzaz. 1982a. Response of plants from three successional communities to a nutrient gradient. J. Ecol. 70:233248.

Parrish, J.A.D. and F. A. Bazzaz. 1982b. Competitive interactions in plant communities of different successional ages. Ecology. 63:314320

Perez-Leroux, H.A.J. and S. D. Long. 1994. Growth analysis of contrasting cultivars of Zea mays L. at different rates of nitrogen supply. Ann. Bot. (Lond.) 73:507-513.

Qasem, J. R. 1992. Nutrient accumulation by weeds and their associated vegetable crops. J. Hortic. Sci. 67:189-195.

Radin, J. W. 1983. Control of plant growth by nitrogen: differences between cereals and broadleaf species. Plant Cell Environ. 6:6566.

[SAS] Statistical Analysis Systems. 1990. SAS/STAT User's Guide. Version 6, 4th ed. Cary, NC: Statistical Analysis Systems Institute. Pp. $1135-1193$.

Sinclair, T. R., and R. C. Muchow. 1995. Effects of nitrogen supply on maize yield, I: modeling physiological responses. Agron. J. 87:632641.

Tollenaar, M., S. P. Nissanka, A. Aguilera, S. F. Weise, and C. J. Swanton. 1994. Effect of weed interference and soil nitrogen on four corn hybrids. Agron. J. 86:596-601.

Wienhold, B. J., T. P. Trooien, and G. A. Reichman. 1995. Yield and nitrogen use efficiency of irrigated corn in the Northern Great Plains. Agron. J. 87:842-846.

Wulff, R. D. and F. A. Bazzaz. 1992. Effect of the parental nutrient regime on growth of the progeny in Abutilon theophrasti (Malvaceae). Am. J. Bot. 79:1102-1107.

Received September 9, 2005, and approved December 12, 2005. 